\title{
Sovereignty and Survivance-The Pathways of Native Politics
}

\author{
Daniel Carpenter
}

K ennan Ferguson's thoughtful and provocative essay lays bare some troubling, even shameful realities. Native Americans are all but invisible in political science, not just in their physical absence from the professional ranks of our discipline, but relatedly, in their thematic and conceptual disappearance from what we study and how we approach it.

Reading this from Cambridge, Massachusetts is both gratifying and painful. Gratifying because two years ago, before I had seen Professor Ferguson's essay, I joined the Harvard University Native American Program (HUNAP) in planning a conference on "Native politics." The conference, entitled "Native Peoples, Native Politics," was held at the Radcliffe Institute for Advanced Study in April 2016. ${ }^{1}$ It was deeply moving, widely attended, and testified to the rich questions that political science daily ignores. Painful because the invisibility of Natives in political science is replicated here at Harvard itself. Across its many schools, Harvard has 60 African-American ladder faculty members, 62 Latino ladder faculty members, but not a single Native American ladder faculty member. ${ }^{2}$

Those experiences and others working with the Native community lead me to side with Ferguson on most of his points. They also lead me to depart from his diagnoses and prescriptions on a few. The active reality of Native American politics is fluid, characterized by telling successes as well as failures, and some of the very concepts Ferguson disparages (such as sovereignty and the rule of law) not only have important indigenous legacies but also active political meaning today.

Daniel Carpenter is Freed Professor of Government, Director of the Social Sciences Program at Radcliffe, and Member of the Provost's Council on Native and Indigenous Issues, HarvardUniversity (dcarpenter@gov.harvard.edu).He thanks Ned Blackhawk, Rick Jemison of the Seneca Nation, Maggie McKinley, and Richard White for many conversations in which the impressions communicated here took shape. I remain solely responsible for all characterizations, omissions and errors.

\section{An Institutional Invisibility}

Kennan Ferguson's larger argument holds true not just within political science at large but especially within the study of American politics and, what is more, in the study of American political development. Aside from Laura Evans' searching essay in the American Political Science Review in 2011 and a few other works, ${ }^{3}$ the American politics literature has been woefully silent on how tribal governments engage in advocacy and coalition-building, or how Native American individuals and communities navigate turbulent and dangerous currents of ethnic and racial politics.

The two more historical communities in the American politics subfield-American political development and social policy, respectively-have done no better. APD's emphasis upon the nation state (and upon state-building as "development") marginalizes indigenous governance even as it neglects settler colonial legacies of violence. ${ }^{4}$ Important works by Kevin Bruyneel, Paul Frymer, and Carol Nackenoff notwithstanding, ${ }^{5}$ APD's deep neglect of Native American political development before, during, and after European colonization reinforces Ferguson's larger point about the erasures of political science. Similarly, a large literature in social policy actively (and appropriately) grapples with issues ranging from racial politics, the carceral state, immigration and rights, the oppression and liberation of non-heterosexual identities and bodies, to race, ethnicity and health policy. Yet despite the living presence of five million Native Americans, next to nothing is written on Native American politics and policy within political science today.

\section{On Sovereignty and Survivance}

On other matters, I think Ferguson's summary misleads. $\mathrm{He}$ writes that "Indigenous patterns of thought overtly oppose many of the values that the United States presumes: the legitimacy of majoritarian democracy, the primary of sovereignty, the rule of law, and especially American exceptionalism." On majoritarian democracy and American exceptionalism, I am in agreement. Not so on the rule of law, which as concept and as metaphor was 
and remains an animating force in many Native American communities. Native Americans have invested heavily in legal expertise and in building a federal bar. So too, Native Americans performed skillful innovations in early American petitioning, using complaints to administrative agencies to induce different parties to monitor treaty compliance. The idea of shaping, reshaping and surveilling treaty agreements-honoring a different rule of law, that of alliances sanctioned by indigenous sovereignty-suffuses so much of Native American politics then and now that I think it is impossible to do away with the concept. Better to refashion it. ${ }^{6}$

In some cases, hard and creative political work in shaping, monitoring, and even revising treaties has led to real and non-trivial gains. Seneca petitioning and advocacy in the 1830s and 1840s led to the partial reversal of the fraudulent Buffalo Creek Treaty, creating the basis for the sovereignty and appreciable success of today's Allegany and Cattaraugus reservations in Seneca Nation. ${ }^{7}$ Those battles established Seneca orator Sagoyewatha (Red Jacket) as another in the line of political leaders and thinkers whose writings should be taught in political science. $^{8}$ Similar developments occurred in Michigan among the Ojibwe and Odawa. And in the late 1960s, the Taos pueblo successfully built alliances and public support for the return of its sacred space at Blue Lake, leading to a landmark congressional statute signed by President Nixon in 1970. The transfer of 48,000 acres of land and waterscape from the settler republic to the indigenous community, in the midst of Nixon's southern strategy and renewed racial tensions in the United States, deserves searching analysis.

What should we call these various efforts, whether successful or not-advocacy? Diplomacy by another name, or what the Iroquois call kaswentha? Many Native American leaders, whether individual tribal members or those at the National Congress of American Indians, are unafraid to use the term "lobbying" to describe part of what they do, and sovereignty provides both means and an ends to justify these practices. Tribal sovereignty remains an important principle in American Indian law, and tribes have fought for such principles-not simply their rights, but their rights to govern themselves-for centuries. What Gerald Vizenor called survivance-that ability to perform persistence and sustained presence physicially, spatially, culturally, narratively-forms an appropriate subject for political science. ${ }^{9}$ How do dispossessed peoples variably contest settler societies? What are the tools with which they do so? Asking not only how dispossession occurred, but how it has been contested, how tribal sovereignty has been built, rebuilt, protected against overwhelming odds and institutional hostility-strike me as fundamental questions of institutional political science. It remains our collective task to embrace them.

\section{Notes}

$1 \mathrm{https}: / /$ www.radcliffe.harvard.edu/event/2016-nativepeoples-native-politics-conference; (accessed April 20, 2016); includes a link to the full conference video.

2 By "ladder" I mean tenure-track; Harvard University, 2015. Of 1,485 ladder faculty at Harvard, "we have only 60 who are Black, 62 who are Latino, and none who are Native American."

3 Evans 2011.

4 Blackhawk 2006.

5 This is a simple but not inaccurate summary of the APD literature. Bruyneel 2004; 2007; Frymer 2014; Nackenoff 2006, ch. 9. An earlier work on removal by Michael Rogin (1975) broke new ground in its psychologically-inspired study of anti-removal ideology and action, though like many works of its time it focused more on Jackson than on Native Americans and tended to depict the latter as passive objects of removal.

6 Carpenter 2016. What Ferguson would wish to say, I think, is that Native Americans in their thought and practice effectuate a different kind of sovereignty, one not wedded to colonial projects, one rooted in attachment to spaces, lands and waterscapes, one that lives apart from the capitalist state.

7 Hauptman 2011.

8 Ganter 2006.

9 Vizenor 2008. Vizenor crafted the term from the French, as he made clear in a November 2014 poetry reading at the Radcliffe Institute at Harvard.

\section{References}

Blackhawk, Ned. 2006. Violence over the Land: Indians and Empire in the Early American West. Cambridge: Harvard University Press.

Bruyneel, Kevin. 2004. "Challenging American Boundaries: Indigenous People and the "Gift" of U.S. Citizenship." Studies in American Political Development 18(1): 30-43.

2007. The Third Space of Sovereignty: The Postcolonial Politics of U.S.-Indigenous Relations. Minneapolis: University of Minnesota Press.

Carpenter, Daniel. 2016. "On the Origins of the Administrative Petition: Innovations in NineteenthCentury Native America." In Administrative Law form the Inside Out: Essays on Themes in the Work of Jerry Mashaw, ed. Nicholas Parrillo. New Haven, CT: Yale University Press.

Evans, Laura E. 2011. "Expertise and Scale of Conflict: Governments as Advocates in American Indian Politics." American Political Science Review 105(4): 663-82.

Frymer, Paul. 2014. "'A Rush and a Push and the Land Is Ours': Territorial Expansion, Land Policy, and U.S. State Formation." Perspectives on Politics 12(1): 119-44. 
Ganter, Granville. 2006. The Collected Speeches of Sagoyewatha, or Red Jacket. Syracuse, NY: Syracuse University Press.

Harvard University. 2015. "Ten Year Trends in Ladder Faculty, 2006-2016." Office of Faculty Development \& Diversity. Available at http://faculty.harvard.edu/ fdd-annual-reports.

Hauptman, Laurence M. 2011. The Tonawanda Senecas' Heroic Battle against Removal. Albany: SUNY Press.

Nackenoff, Carol. 2006. "Constitutionalizing Terms of Inclusion: Friends of the Indian and Citizenship for
Native Americans, 1880s-1930s," In The Supreme Court and American Political Development, ed. Ronald Kahn and Ken I. Kersch. Lawrence: University of Kansas Press.

Rogin, Michael. 1975. Fathers and Children: Andrew Jackson and the Subjugation of the American Indian. New York: Knopf.

Vizenor, Gerald. 2008. "Aesthetics of Survivance: Literary Theory and Practice." In Survivance: Narratives of Native Presence, ed. Gerald Vizenor. Lincoln: University of Nebraska Press. 